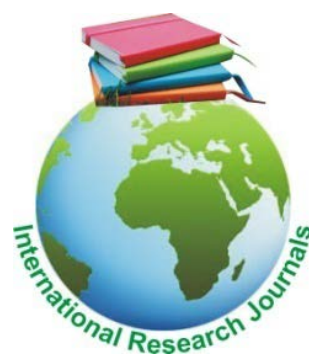

African Journal of Food Science and Technology (ISSN: 2141-5455) Vol. 9(3) pp. 59-64, Nov, 2018

DOI: http:/dx.doi.org/10.14303/ajfst.2018.237

Available online https://www.interesjournals.org/food-science-technology.html

Copyright (C)2018 International Research Journals

\title{
Thermoprocessment of tambaqui fish in tucupi sauce
}

\author{
Nhavoto VM ${ }^{1 *}$, Carpio $\mathrm{KCR}^{2}$, Inhamuns $\mathrm{AJ}^{2}$
}

${ }^{1}$ Fishery School, Ministry of Sea Inland Waters and Fisheries,Maputo, Mozambique.

${ }^{2}$ Faculty of Agricultural Sciences, Fish Technology Laboratory,Federal University of Amazonas, Manaus, Brazil.

*Corresponding Author Email: vnhavoto@gmail.com

\begin{abstract}
Canning of juvenile tambaqui (Colossoma macropomum) was carried out using "tucupi" cover dressing (regional sauce) and the acceptability of the preserve was tested. Cans were thermally processed at $121^{\circ} \mathrm{C}$ for 20 mins, 25 mins and 30 mins. The "in natura" centesimal composition and the products were determined according to A.O.A.C, commercial sterility and microbiological quality was verified and the Kruskal-Wallis ANOVA was used to evaluate the results of the study. Cans with heat treatment of $121^{\circ} \mathrm{C}$ for 30 mins showed better bone decalcification and its centesimal composition was $71.29 \%$ of humidity; $20.98 \%$ protein; $5.87 \%$

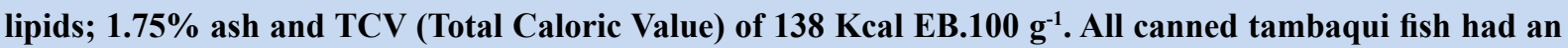
acceptance index above $95 \%$ and intention to buy above 5 (would eat frequently). The "tucupi" sauce was approved by $100 \%$ of the evaluators and its use for canning has the advantage of the great availability of the raw material (wild cassava), resulting in a low production cost and a new type of product offering to the consumers.
\end{abstract}

Keywords: Colossoma macropomum, Canned fish, Fish farming.

\section{INTRODUCTION}

Fish conservation by canning is used in some regions of the world and has advantages such as ease of handling, reduced risk of fish contamination and ease of transport. In 2014, 46\% (67 million tonnes) of fish intended for human consumption was fresh or chilled, the remainder of food production was processed in different ways: about 12\% (17 million tonnes) dried, salted, smoked or cured; $13 \%$ (19 million tons) canned; and 30\% (about 44 million tonnes), frozen (FAO, 2016). The lack of adequate equipment and the availability of electricity make it difficult for conservation of fish in some regions. According to Kent (1988) the development of the canning industry may be an alternative to reduce postharvest losses. In the African continent few countries have canning industries, in Zimbabwe (Kariba) a factory for the sardine of the Tanganyika, kapenta (Limnothrissa miodon) has already been installed. South Africa is one of the countries that exports to Swaziland in sub-Saharan Africa. In the Kingdom of Morocco canning of fish is a very old tradition dating back to the 1929s. Morocco's fish preserves enjoy a worldwide reputation and more than
$90 \%$ of the production is exported mainly to Europe, West Africa, North America and Middle East (Kent, 1998). The fish raw material is a constant concern for fish canning industry, due to the need to import raw materials, scarcity and seasonality of supplies, as well as international catch agreements (Beuren, 2012). In the past decades the oceans were an exclusive source of fish for canning, but in some regions there is currently a shortage of fish related to several factors, but the availability of fish from fish farming has contributed to the research of canning some species in Brazil such as tilapia (Oreochromis niloticus), lambari (Astianax spp), pacu (Piaractus mesopotamicus) (Dutra et al., 2012) and jundiá (Rhamdia quelen), (Cozer et al., 2014). Tambaqui is the native specie of South America with the high production in Brazilian aquaculture, being able to measure $100 \mathrm{~cm}$ and weight around $30.0 \mathrm{~kg}$ in its habitat (Kubitza, 2004: 2015). According to Souza and Inhamuns (2011), tambaqui is a specie with good meat yield for use in several technological processes. The term tambaqui "curumim" refers to the small tambaqui of about $500 \mathrm{~g}$ widely consumed, marketed chilled or frozen, whole eviscerated and with longitudinal cuts on the back to reduce the size of intramuscular spines 
(Gandra, 2010). Fish farming can be a potential driver of the fish processing industry because it does not suffer large fluctuations (periods of abundance and scarcity) in the supply (Santos and Gonçalves, 2011; Viana et al., 2016). The use of fish farms for the production of canned fish can diversify the marine preserves and the use of cover liquids, such as tucupi, may be a less expensive alternative compared to tomato juice. The tucupi is the yellow liquid extracted from the root of the wild cassava when it is peeled, grated and pressed; is used in cooking of the regions North and Northeast of Brazil, especially in the monitoring of fish-based dishes. The elaboration of tucupi consists of heating at high temperatures occurring the hydrolysis of cyanogenic compounds and the volatilization of cyanide ( $\mathrm{CN}$ ) to the environment (Chisté et al., 2007:2011). Hydrolysis allows the release of HCN (cyanidric acid) that confers toxicity to the product and that will be beneficial since cyanides are harmful to human health. This experiment focused to evaluate the conditions of treatment that promote the softening of the bones of juvenile tambaqui ( $\leq 500 \mathrm{~g}$ ) and the acceptability of the canned tambaqui in tucupi sauce.

\section{MATERIALS AND METHODS}

\section{Raw material}

The fish used for canning were $10 \mathrm{~kg}$ of tambaqui juveniles weighing between $355 \mathrm{~g}$ to $400 \mathrm{~g}$, purchased from regional fish farmers registered at the State Secretariat of Rural Production (SEPROR). The fish were washed with treated water and packaged in a 2:1 ice isothermal box to guarantee the freshness quality of the fish, taking into account the climatic conditions of the region and transported to the fish technology laboratory of the Federal University of Amazonas (UFAM).

\section{Treatment of raw material}

The weighing was performed to calculate the meat yield, then the fins were cut and the scales removed, followed by removal of the vertebral column. The flatfish were sectioned and received $20 \%$ brine for 15 mins.

\section{Preparation of the cover dressing}

To elaborate the cover dressing, commercial soybean oil, regional tucupi sauce ( $10 \%$ oil for each $1 \mathrm{~L}$ of tucupi) and condiments (onion, garlic, chilli pepper, coriander and chives) were used in the proportion of $2 \%$ to $1 \mathrm{~L}$ of the mixture of oil and tucupi. The tucupi used for the cover dressing was purchased in the local market and was previously sterilized and inspected. The tucupi available in the markets of Manaus is of homemade manufactured and sometimes the quality is low in the attributes of color, being pale yellow and flavor less accentuated because of the small amount of condiments added. Thus there are certified companies producing the product due the high demand. The inspection aims to to detect possible changes. The company must certify that the tucupi has been prepared according to good manufacturing practices and complying with the necessary boiling time for cyanide volatilization, ensuring the safety of consumers.

\section{Canning, pre-baking and pickling}

The cans were made of tin sheets, circular in shape with $\varnothing$ $99 \mathrm{~mm} \times 117 \mathrm{~mm}$, coated with epoxy-phenolic lacquer, with a capacity of approximately $650 \mathrm{~g}$ (net weight). Each can received an approximate amount of $200 \mathrm{~g}$ of fresh fish, alternating between slices (loin and ribs) and tails. The pre-baking was steamed in an autoclave for 20 mins at a temperature of $100^{\circ} \mathrm{C}$ and a pressure of $0.5 \mathrm{~kg} / \mathrm{cm}^{2}$ and at the end of the process the resulting exudate liquid was about $7.5 \%$ by weight of fresh fish or $185 \mathrm{~g}$ of precooked fish per can. The cans were filled with approximately 340 $\mathrm{g}$ of tucupi-containing cover dressing, preheated at 80$90^{\circ} \mathrm{C}$ for 8 mins and held for $1-2$ mins, then hermetically sealed in a semi-automatic recravator machine.

\section{Heat treatment}

The sterilization of the products was performed in a vertical autoclave using three treatments at 20,25 and 30 mins of exposure, with a constant temperature of $121^{\circ} \mathrm{C}$ and a pressure of $1.2 \mathrm{~kg} / \mathrm{cm}^{2}$. The three heat treatments were applied to the canned tambaqui with 9 replicates in each treatment. The cans were then cooled and stored at room temperature.

\section{Physicochemical analysis}

The analyzes of centesimal composition (moisture, protein, lipids, ash and carbohydrates), $\mathrm{pH}$ and sodium chloride content were performed in triplicate in the "in natura" and canned samples, according to the methods of Adolfo Lutz Institute Analytical Standards (Sao Paulo, 2008). The total caloric value was calculated and expressed in kilocalories (kcal) according to Resolution RDC nr. 360-ANVISA (National Sanitary Surveillance Agency) (Brazil, 2003).

\section{Determination of sodium chloride and pH}

After preparation of the cane, the content of chlorides was determined by the volumetric technique according to the Adolfo Lutz Institute's Analytical Standards (Sao Paulo, 2008) and the $\mathrm{pH}$ using bench $\mathrm{pH}$ meter.

\section{Commercial sterility test}

The product was analyzed for commercial sterility, according to Deibel \& Jantschke (2001). Thus, observations of possible canning of the cans were made during the five days of analysis, after stoving at $55^{\circ} \mathrm{C}$; and on the tenth day after storage at $35^{\circ} \mathrm{C}$. 


\section{Microbiological analyses}

To evaluate the hygienic-sanitary conditions of the canned tambaqui, microbiological analyzes were carried out by evaluation of quality parameters following the "official analytical methods for microbiological analyzes to control products of animal origin and water", described by Administrative Rule nr. 62-MAPA (Ministry of Agriculture and Fisheries) (Brazil, 2003). Microbiological analyzes were carried out on canned products, randomly selected in triplicate for the three treatments, by means of the evaluation of canning quality parameters for the following microorganisms: Staphylococcus aureus, Total coliforms Salmonella sp. and thermotolerant coliforms.

The study of Clostridium botulinum was carried out by sowing the sample in Base Agar (M 836) for the genus Clostridium prepared according to the procedures described in the Manual of Microbiology Laboratory (HIMEDIA, 2009) and incubation in anaerobic condition $35^{\circ} \mathrm{C}$ for $48 \mathrm{~h}$, with subsequent reading. The agar composition was based on the following ingredients: proteose peptone (40 g/L); disodium phosphate (5 g/L); monopotassium phosphate $(1 \mathrm{~g} / \mathrm{L})$; magnesium sulfate $(0.1 \mathrm{~g} / \mathrm{L})$; sodium chloride $(2 \mathrm{~g} / \mathrm{L})$; fructose $(6 \mathrm{~g} / \mathrm{L})$ and agar $(15 \mathrm{~g} / \mathrm{L}) ; \mathrm{pH}$ adjustment $\left(25^{\circ} \mathrm{C}\right)$ for 7 to $7.4 \pm 0.2$. Sample preparation was done by disinfecting the can opener and the packaging with $70 \%$ ethanol disinfectant solution.

\section{Sensory analysis}

Sensory analyzes were performed at the Faculty of Agrarian Sciences of the Federal University of Amazonas by 90 non-trained tasters, after presentation of the signed "Free and Informed Consent Term". The three canned tambaqui samples were coded and presented individually, in random order.

In the acceptability test, a nine-point hedonic scale was used for the attributes of appearance, color, odor, taste, texture and overall impression, anchored at its extremes with the terms "extremely disagreeable" (1) to "extremely liked" (9). The Acceptability Index (Al) was calculated using the following equation: $\mathrm{Al}(\%)=A \times 100 / B$, where: $A=$ average score obtained for the product, and $B=$ maximum score given to the product (Dutcosky, 2013). The attitude test was applied to evaluate the consumption intention of the canned tambaqui, where each judge evaluated their consumption attitude before each sample on a sevenpoint scale ranging from "never eat" (1) to "always eat" (7) (Sao Paulo, 2008).

\section{Statistical analysis}

To test the normality and homoscedasticity, the centesimal composition and sensory analysis data were submitted to the Shapiro-Wilk and Bartlett tests, and treated statistically by ANOVA-analysis of variance at a 5\% probability level (Zar, 2010). The Kruskal-Wallis ANOVA was used to test the acceptability and attitudes of consumption among the three treatments, followed by the Tukey test in the PMCMR package of the R program. For all statistical analyzes, $p<0.05$ was used. Statistical analyzes were performed using software $\mathrm{R}$ version 3.1.3 (R Development Core Team, 2009).

\section{RESULTS AND DISCUSSION}

The average weight of the specimens used was $380 \pm$ $0.01 \mathrm{~g}$; the total length $10.5 \pm 0.45 \mathrm{~cm}$, the body cleaned $245 \pm 0.03 \mathrm{~g}(63.8 \%)$; flat belly, with skin and head $187 \pm$ $0.02 \mathrm{~g}(51 \%)$. Despite the small size, the percentages of yield found for "curumim" tambaqui from fish farming were considered high (Souza and Inhamuns, 2011; Cartonilho and Jesus, 2011). The centesimal composition and total caloric value of the samples of canned "curumim" tambaqui and "in natura" are shown in Table 1.

An increase in the fractions was observed when compared to the "in natura" and preserved samples. However, there was no significant difference in the fractions studied between the cooking times tested. Only the Total Caloric Value (TCV) was different among the treatments, being larger with 20 mins and smaller with 25 mins.

Canned tambaqui presented $\mathrm{pH}$ values of $5.07 \pm 0.02$; $4.93 \pm 0.06 ; 4.93 \pm 0.01$ for the sauce and $5.23 \pm 0.04$; $5.07 \pm 0.02 ; 4.97 \pm 0.02$ for the meat in the treatments of 20,25 and 30 mins, respectively. This condition was influenced by the physicochemical properties of tucupi, which may favor the storage of the canned product due

Table 1: Centesimal composition of samples of and sodium chloride content the canned tambaqui "curumim".

\begin{tabular}{|c|c|c|c|c|c|c|c|}
\hline \multicolumn{8}{|c|}{ Centesimal composition (\%) } \\
\hline \multirow{2}{*}{ Tambaqui curumim } & \multirow{2}{*}{ Moisture } & \multirow{2}{*}{ Protein } & \multirow{2}{*}{ Lipids } & \multirow{2}{*}{ Ash } & \multirow{2}{*}{ Carboihydrates } & Sodium & TCV \\
\hline & & & & & & chloride (mg) & (Kcal EB.100 g-1) \\
\hline " in natura" & $78.35 \pm 0.81$ & $18.44 \pm 0.5$ & $2.46 \pm 0.13$ & $0.72 \pm 0.03$ & 0.09 & & 97 \\
\hline \multicolumn{8}{|l|}{ Cooking time (minutes) } \\
\hline 20 & $68.60 \pm 2.84^{a}$ & $22.23 \pm 0.76^{a}$ & $6.54 \pm 0.12^{\mathrm{a}}$ & $2.52 \pm 0.12^{\mathrm{a}}$ & $0.11^{\mathrm{a}}$ & 540 & $152^{\mathrm{a}}$ \\
\hline 25 & $72.69 \pm 1.34^{a}$ & $19.36 \pm 0.32^{\mathrm{a}}$ & $5.80 \pm 0.28^{a}$ & $1.77 \pm 0.13^{a}$ & $0.38^{a}$ & 540 & $134^{\mathrm{b}}$ \\
\hline 30 & $71.29 \pm 1.77^{a}$ & $20.98 \pm 0.64^{a}$ & $5.87 \pm 0.03^{a}$ & $1.75 \pm 0.35^{\mathrm{a}}$ & $0.11^{\mathrm{a}}$ & 540 & $138^{\mathrm{ab}}$ \\
\hline
\end{tabular}

Note: Equal letters $(a, b)$ in the same column do not represent significant differences $(p>0.05)$ between the samples. The determinations were made on a dry matter. 
to its low acidity. Larrouse and Brown (1997) cite that the microorganisms of the genus Clostridium develop best at $\mathrm{pH}$ values close to neutrality which is generally observed in fish products and their rates of growth are reduced with decreasing $\mathrm{pH}$ however to ensure that Clostridium growth does not occur, $\mathrm{pH}$ should be below 4.6. Table 2 shows the results of the microbiological analyzes of the preserves.

The results show that there was no microbial growth in any of the analyzes performed for the three treatments (20, 25 and 30 mins). Botulism is a common intoxication in canned products caused by a preformed toxin in the food originated by Clostridium botulinum. The analyzes in the three treatments evidenced the absence of the bacteria. The cooking to eliminate the risk of botulism has been defined as the equivalent to 3 mins at $121^{\circ} \mathrm{C}$, this value is also referred to as $\mathrm{F}_{0}$ value or "commercial sterility value" (Huss, 1997). The absence of the bacteria Staphylococcus aureus and Salmonella spp. in the samples confirm the sanity of the product and the compliance with the hygienic and sanitary procedures during the processing. The results show that there was no activity of strict thermophilic bacteria, that is one of the causes of deterioration of canned foods. According to Da Silva et al. (2007), the most common alterations are: "flour-sour" deterioration, caused by $C$. stearothermophilus, which results in a reduction of the $\mathrm{pH}$ without puffing; anaerobic deterioration without $\mathrm{H}_{2} \mathrm{~S}$ production, caused by $T$. thermosaccharolyticum, which results in cheese odor and pronounced packaging fuming; anaerobic thermophilic deterioration with $\mathrm{H}_{2} \mathrm{~S}$ production, caused by $D$. nigrificans, which results in blackening of the contents $\left(\mathrm{H}_{2} \mathrm{~S}\right.$ reaction with iron), without packaging jamming.

During the quarantine period, no deformations of the packages were detected and after opening, they did not present microbial contamination, indicating the effectiveness of the heat treatment and the recravation. The results of the sensorial analyzes did not show differences in the meat of canned tambaqui submitted to the three distinct times of autoclaving (Table 3).

However, there was a significant difference between the times applied $(p<0.05)$ in the canned tambaqui when the softening of the bones was compared (Table 4).

The high yield achieved by tambaqui "curumim" was probably due to the maintenance of the bones of the ribs, in an intentional way, since the rib is the cut preferred by the habitual consumers of this species, besides the presence of the bones raises the available calcium content in the canned fish (Manthey-Karl et al., 2014).

The reduction of the moisture content in the preserves relative to the "in natura" matter is related to the precooking step, which results in the expulsion of water from the tissues, which concentrated the other components of the composition, in the three treatments. According to Pardi et al. (2007) the spices contain plant components, such as proteins, carbohydrates, fixed oils, tannins, pigments, mineral elements, etc., but the amount of condiments used was small for the increase in the concentration of the components which can be attributed to the soy oil. The tucupi used did not contribute to the elevation of the

Table 2: Microbiological evaluation of the product (canned tambaqui)

\begin{tabular}{|c|c|c|c|c|c|}
\hline \multirow{2}{*}{$\begin{array}{c}\text { Cooking time } \\
\text { (Minutes) }\end{array}$} & C. botulinum in $25 \mathrm{~g}$ & Coliformes totais & S. aureus & Salmonella in $25 \mathrm{~g}$ & Sterility at $55^{\circ} \mathrm{C}$ \\
\hline & CFU. g- ${ }^{-1}$ & MPN. $g^{-1}$ & CFU. g- ${ }^{-1}$ & CFU. g- ${ }^{-1}$ & Thermophilic m.o \\
\hline 20 & Absent & $<3.0$ & Absent & Absent & No change \\
\hline 25 & Absent & $<3.0$ & Absent & Absent & No change \\
\hline 30 & Absent & $<3.0$ & Absent & Absent & No change \\
\hline
\end{tabular}

Table 3: Acceptance test and consumption attitude of canned tambaqui in tucupi sauce.

\begin{tabular}{|l|c|c|c|}
\hline \multirow{2}{*}{ Sensory attributes } & \multicolumn{3}{|c|}{ Cooking time ( min) } \\
\cline { 2 - 4 } & $\mathbf{2 0}$ & $\mathbf{2 5}$ & $\mathbf{3 0}$ \\
\hline Appearance & 7.7 & 7.6 & 7.8 \\
\hline Color & 7.5 & 7.7 & 7.7 \\
\hline Odor & 7.4 & 7.8 & 7.2 \\
\hline Flavor & 7.9 & 7.2 & 7.3 \\
\hline Texture & 7.7 & 7.3 & 7.3 \\
\hline Global impression - GI & 7.7 & 96.9 & \\
\hline Acceptability index - Al (\%) & 96.8 & 5.5 & \\
\hline Attitude of consumption & 5.5 & 5.8 & \\
\hline
\end{tabular}

Table 4: Wilcoxon test for bone softening in the three treatments by non-experienced $(n=90)$ and experienced $(n=10)$ consumers.

\begin{tabular}{|c|c|c|}
\hline Cooking time (minutes) & Non-experience consumers $(\mathbf{p})$ & Experienced consumers (p) \\
\hline $20^{\mathrm{a}}$ e $25^{\mathrm{a}}$ & 0.9033 & 0.0636 \\
\hline $20^{\mathrm{a}}$ e $30^{\mathrm{b}}$ & 0.0013 & 0.0014 \\
\hline $25^{\mathrm{a}}$ e $30^{\mathrm{b}}$ & 0.0146 & 0.0044 \\
\hline
\end{tabular}

Note: $a$ and $b$ are equal letters in the same row, treatments did not differ $(p>0.05)$. 
protein content, since it contains low protein contents, between 0.33 and 0.66\% (Chisté et al., 2007:2011).

The elevation of the lipid content in the preserves was mainly attributed to the fraction of soybean oil used in the cover dressing. Aubourg (2001) and Rasmussen and Morrissey (2007) state that when oil is used as a cover medium, there are interactions between the fatty acids of the oil and the lipid fraction of the fish muscle, with a slight increase in fatty acids.

The immersion of the fish in brine contributed to the increase of the ash content, considering that the sodium content of the canned tambaqui, in a $60 \mathrm{~g}$ portion was $540 \mathrm{mg}$, higher than that of commercially available sardine preserves whose declared levels are $330 \mathrm{mg} / 60$ g. Due to the opening of the fish it is necessary to prepare a brine of lower concentration (10\%). The canning, besides preserving the product in the absence of the cold chain, makes the meat ready for consumption and due to the action of heat the bones take a soft texture, providing an important source of calcium (Aubourg, 2001; Santos and Gonçalves, 2011; El-Sherif and El-Ghafour, 2015). In the processed canned tambaqui fish no changes were observed in the samples (cans) or gas production after the sterility test indicating the absence of microbial activity under the study conditions.

Even without significant difference, the treatment with 20 mins reached greater acceptance, influenced by the texture of the meat, closer to the term "I liked it very much". In the Index of Acceptability (I.A.), no significant differences were observed either, with all products presenting indices above 95\%, revealing their commercial viability. However, the treated canning with 30 mins of cooking had nominally a lower percentage in the acceptability index, probably due to the taste and odor attributes.

In the analysis of consumer attitude did not present significant difference, where the products reached the intention "would eat frequently".

Regarding the taste of the tucupi sauce all the consumers said they liked it (100\%). Although the tucupi broth had unusual characteristics (odor and flavor) of the traditional preserves, the cover sauce was accepted by the natives of the Amazon region and by other consumers of other naturalities. The use of this cover dressing is less costly compared to tomato or oil based sauces and can be applied by the low cost canning industry. The tucupi sauce used is a byproduct of cassava processing, widely produced and commercialized, and can be used extensively in the technological process and stimulate the cassava processing industries and the canning industry.

In the elaboration of the canned tambaqui "curumim", the dorsal spine was removed to reduce the amount of bones to be submitted to thermal processing, but the intramuscular and rib bones were maintained. In this context, the size of the canned fish, the pre-baking and the treatment of the fish before canning are factors that probably affected the softening of the bones. Canned tambaqui sterilized for 30 mins showed better bone fragmentation, with $70 \%$ of consumers considered the soft bones and the comments were "fully edible spines", "easily digestible smaller spines". However there were still comments on "rib spines a little hardened". In this sense, in order to have a higher percentage of softening of the spines, smaller specimens with $300 \mathrm{~g}$ on average could be used.

\section{CONCLUSIONS}

The processing time of the canned tambaqui at $121^{\circ} \mathrm{C}$ for 30 mins was efficient in softening the spines/bones of tambaqui curumim with an average weight of $380 \mathrm{~g}$, but the reduction in the average weight of the fish is advisable.

The tucupi cover dressing obtained great acceptance, however the consumers recommend the reduction in the percentage of added oil.

The preserves presented high values of sodium according to the comments of some consumers, so it is recommended to reduce the percentage of salt or the time of brining of the slices.

\section{DECLARATION OF CONFLICTING INTERESTS}

The author(s) declared no potential conflicts of interest with respect to the research, authorship, and/or publication of this article.

\section{REFERENCES}

Aubourg SP (2001). Loss of quality during the manufacture of canned fish products. Food. Sci. Tech. Int. 7(30): 199-215.

Beuren IM, Cardoso RS (2012). Performance of the marketing area in Brazilian and Spanish fish canning industries in the face of fish shortages. Regional University of Blumenau.

Brazil (2003). Ministry of health. National sanitary surveillance agency. Compulsory Nutrition Labeling.

Brazil (2003). Ministry of agriculture, livestock and supply. Secretariat of agricultural and livestock protection. Official Analytical Methods for Microbiological Analysis for the Control of Animal and Water Products.

Cartonilho MM, Jesus RS (2011). Quality of frozen cuts of cultivated tambaqui. Pesquisa Agropecuária Brasileira 46(4): 344-350.

Chisté RC, Cohen KO, Oliveira SS (2007). Study of the chemical properties of tucupi. Food. Sci. Tech. 27(3): 437-440. 
Chisté RC, Cohen KO (2011). Total and free cyanide content in the processing stages of tucupi. Rev. Inst. Adolfo. Lutz. 70(1): 41-46.

Cozer N, Signor A, Feiden A, Silva AM, Boscolo WR (2014). Canning protocol of silver catfish and proximate, microbiological and sensorial characterization of the final product. Boletim do Instituto de Pesca 40(1): 61-68.

Da Silva N, Junqueira VCA, Silveira NFA, Marta HT, Rosana FSS, Renato ARG (2007). Manual of microbiological food analysis methods. In: Varela book store ( $3^{\text {rd }}$ eds), Sao Paulo.

Deibel KE, Jantschk M (2001). Canned foods-Tests for cause of spoilage. In: Downes, F.P. \& Ito, K. (4theds). Compendium of Methods for the Microbiological Examination of Foods, Washington, American Public Health Association.

Dutcosky SD (2013). Sensory analysis of food. ( $4^{\text {th }}$ eds), Curitiba: Champagnat, Brazil.

Dutra FM, Machado WJ, Caetano MS, Gobbo DA (2012). Sensory evaluation of canned processing, using the species: tilapia (Oreochromis niloticus), lambari (Astianax spp) and pacu (Piaractus mesopotamicus). Braz. J. Agroind. Prod. 14(3): 239-244.

El-Sherif SA, El-Ghafour SA (2015). Nutritive value of canned River Nile cryfish (Procambarus clarkii) products. Egypt J. Aquat. Res. 41(3): 265-272.

FAO (2016). The state of world fisheries and aquaculture. Contribution to food security and nutrition for all. Roma

Gandra AL (2010). The fish market of the metropolitan region of Manaus. Series: The fish market in large Latin American cities. INFOPESCA.

Huss HH (1997). Quality assurance of fishery products. FAO Fisheries technical paper 334. Roma.

Kent G (1988). Alleviation malnutrition in southern Africa. Improved use of fisheries resources. Food Policy. 13(4): 341-358.

Kubitza F (2004). Collection of information applied to the cultivation of tambaqui, pacu and other round fish. Panorama de Aqüicultura. 14(82): 27-29.

Kubitza F (2015). Aquaculture in Brazil: Main species, areas of cultivation, rations, limiting factors and challenges. Panorama de Aqüicultura. 25(150): 10-23.

Larousse J, Brown BE (1997). Food canning technology. Wiley-VHC INC, Canada.

Manthey-Karl M, Ostermeyer U, Altinelataman C, Çelik U, Oehlenschläger J (2014). Chemical composition, cholesterol, trace metals and amino acid composition of different canned fish products produced and sold in Turkey. J. Fishscicom. 8(1): 18-26.

Pardi MC, Santos IF, Souza ER, Pardi HS (2007). Science, hygiene and meat technology. ( $\left.2^{\text {nd }} e d s\right)$, Publisher UFG, Brazil.

Rasmussen RS, Morrissey MT (2007). Effects of canning on total mercury, protein, lipid and moisture content in troll-caught albacore tuna (Thunnus alalunga). Food Chem. 101(3): 1130-1135.

R Development Core Team (2009). R: A language and environment for statistical computing. R Foundation for Statistical Computing, Vienna, Austria.

Santos W, Gonçalves AA (2011). Canning of fish. In: GONÇALVES, AA, Fish technology science, technology, innovation and legislation. São Paulo, Atheneu.

Instituto Adolfo Lutz (2008). Physical-chemical methods for food analysis. (4th eds), Analytical Standards of the Adolfo Lutz Institute, Sao Paulo, Brazil.

Souza AFL, Inhamuns AJ (2011). Analysis of meat yield of the main fish species traded in the State of Amazonas, Brazil. Acta. Amazonica. 41(2): 289-296.

Viana AP, Inhamuns AJ, Oliveira PR, Souza LCB (2016). Effect of packaging with modified atmosphere on Brycon amazonicus conservation. Fish. Inst. Bull. 42(1): 17-28.

Zar JH (2010). Biostatistical Analysis. (5 $5^{\text {th }}$ eds), Pearson Prentice Hall, Inc. United States of America. 